\title{
Review \\ Exploring the Role of Testosterone Replacement Therapy in Benign Prostatic Hyperplasia and Prostate Cancer: A Review of Safety
}

\author{
André Rizzuti ${ }^{1}$, Gustavo Stocker ${ }^{2}$ and Heitor O. Santos ${ }^{3, *(\mathbb{D})}$ \\ 1 School of Medicine, Estácio de Sá University (UNESA), Rio de Janeiro 20261-060, RJ, Brazil; \\ Rizzutiandre@gmail.com \\ 2 School of Medicine, University Center Assis Gurgacz Foundation (FAG), Cascavel 85806-095, PR, Brazil; \\ Gustavostockermed@gmail.com \\ 3 School of Medicine, Federal University of Uberlandia (UFU), Uberlandia 38400-902, MG, Brazil \\ * Correspondence: heitoroliveirasantos@gmail.com
}

check for updates

Citation: Rizzuti, A.; Stocker, G.; Santos, H.O. Exploring the Role of Testosterone Replacement Therapy in Benign Prostatic Hyperplasia and Prostate Cancer: A Review of Safety. Uro 2022, 2, 30-39. https://doi.org/ 10.3390 /uro2010005

Academic Editor: Tommaso Cai

Received: 27 December 2021

Accepted: 29 January 2022

Published: 11 February 2022

Publisher's Note: MDPI stays neutral with regard to jurisdictional claims in published maps and institutional affiliations.

Copyright: (c) 2022 by the authors Licensee MDPI, Basel, Switzerland. This article is an open access article distributed under the terms and conditions of the Creative Commons Attribution (CC BY) license (https:// creativecommons.org/licenses/by/ $4.0 /)$.

\begin{abstract}
Increased risk of prostate diseases triggered by testosterone replacement therapy (TRT) remains a worldwide concern. That said, we reviewed the safety of TRT in the spheres of benign prostatic hyperplasia (BPH) and prostate cancer (PCa), exploring clinical findings in this regard. Compelling evidence based on meta-analyses of randomized and observational studies indicates safety for TRT in patients suffering from prostate disorders such as BPH and PCa, at the same time improving lower tract urinary symptoms. Thus, the harmful relationship geared toward androgens and BPH seems to be overestimated as TRT has sufficient safety and, if properly prescribed, may counteract several metabolic problems. Even after PCa treatment, the benefits of TRT could outweigh the risk of recurrence, but further long-term randomized clinical trials are needed to elucidate unresolved questions.
\end{abstract}

Keywords: androgens; benign prostatic hyperplasia; prostate cancer; testosterone; testosterone replacement therapy

\section{Introduction}

Decline in serum testosterone (T) levels is an overt clinical issue, mainly in aging men, and therefore massive scientific effort has been made to better address pharmacological and nonpharmacological strategies in this setting [1-6]. The onset of T decline occurs markedly from the fifth decade of life [7]. Estimates account for $20 \%$ of T deficiency among men aged $60-70$ years, 30\% among men aged $70-80$ years, and 50\% among men aged over 80 years [7]. Besides aging, other pathological conditions can lead to primary and secondary hypogonadism, such as infiltrative diseases, testicular and pituitary trauma, varicocele, cryptorchidism, orchitis, hyperprolactinemia, obesity, and some genetic syndromes [8].

Epidemiological studies show an association of male hypogonadism with greater prevalence and risk of developing cardiometabolic disorders such as dyslipidemia, obesity, diabetes, and hypertension $[9,10]$. Several meta-analyses have shown that men with hypogonadism are at increased risk of all-cause mortality and cardiovascular diseases [7,8,11-13]. Testosterone replacement therapy (TRT), in turn, can ameliorate cardiometabolic parameters and reduce the risk of cardiovascular events [14,15].

Improved well-being and sexual desire are undisputable when male patients suffering from hypogonadism are on TRT [16]. Seemingly, TRT has no major implications for prostate-specific antigen (PSA) levels [17,18]; however, the side effects of TRT on prostate enlargement and related disorders remain a concern, particularly, benign prostatic hyperplasia $(\mathrm{BPH})$ and prostate cancer $(\mathrm{PCa})$, which are commonly responsible for urologist visits, so much so that PCa is the second most prevalent cancer and the fifth leading cause of 
cancer-related mortality in males, mainly affecting middle-aged to elderly patients [19-21]. Thus, we performed a narrative review in an attempt to ascertain the clinical magnitude of TRT on BPH and PCa, with the principal focus on safety.

\section{Material and Methods}

A brief literature search was performed employing Medline, Embase, Scopus, Cochrane Library, and Web of Science from inception to December 2021. The following keywords were used: "hypogonadism" or "testosterone" or "testosterone administration" or "testosterone replacement therapy" or "total testosterone" and "benign prostatic hyperplasia" or "prostate cancer" or "lower tract urinary symptoms". Then, the basic concepts and the clinical findings were discussed in order to unify traditional and recent evidence through a narrative review for practitioners and scientists in the area of urology.

\section{Testosterone Action on Prostate Growth}

T and its 5-alpha-reduced metabolite dihydrotestosterone (DHT) are the main androgens involved in prostate growth and maturation [22]. Although DHT is a vital hormone for embryological differentiation of the prostate during the intrauterine period, it can be considered a triggering factor for prostate disorders such as $\mathrm{PCa}$ and $\mathrm{BPH}$ [23]. Both PCa and $\mathrm{BPH}$ are linked to abnormal prostate enlargement, but with different pathophysiological features [24]. Commonly, the latter is characterized by nodules growing from the peripheral zone, while the latter consists of noncancerous nodules from the transitional zone $[25,26]$.

\section{Diagnosis and Treatment of Benign Prostatic Hyperplasia and Prostate Cancer \\ 4.1. Benign Prostatic Hyperplasia}

The diagnosis of BPH is made on the basis of clinical history and digital rectal examination, which is the first step to verify if there is any degree of abnormality in the dimensions of the prostate [27]. Digital rectal examination is indicated in the fifth decade of a man's life; however, the results are underestimated compared to transrectal ultrasound [28]. The American Urology Association Symptom Index (AUASI) questionnaire is another tool for monitoring BPH. It consists of seven questions that include the main symptoms related to $\mathrm{BPH}$, with specific scores ranging from 0 to 5 in each section, with an overall maximum score of 35 points. Symptom severity can be classified as mild (0-7 points), moderate (8-19 points), and severe (20-35 points). The AUASI has a good correlation with the extent of the patient's urinary problems [29].

Lower urinary tract symptoms (LUTS) are a major concern in patients suffering from $\mathrm{BPH}$ by decreasing their health-related quality of life [30]. LUTS are divided into obstructive and irritative symptoms, which occur due to the mass effect and compression of adjacent structures such as nervous tissue and urethra [31]. Urethral compression impairs urination and may cause incontinence and bladder obstruction through ensuing progress [31].

The treatment of BPH encompasses the use of 5-alpha-reductase inhibitors (i.e., dutasteride and finasteride) and alpha-adrenergic agents (e.g., doxazosin) [32]. These pharmacological agents mitigate BPH progression while improving LUTS [33]. Along these lines, as DHT blockade is a therapeutic approach aimed at decreasing the size of prostate hyperplasia patterns, there is a caution for TRT in patients with BPH or an increased risk of $\mathrm{BPH}$ onset [34]. Although androgen deprivation in adulthood leads to involution of the prostate tissue, serum T and DHT concentrations do not appear to be higher in men who develop BPH [35,36]. For instance, in the Physicians' Health Study, 320 men surgically treated for BPH had similar serum T concentrations-collected up to nine years before BPH surgery-than 320 men who had not developed prostate diseases [37].

\subsection{Prostate Cancer}

PSA values above $4.0 \mathrm{ng} / \mathrm{mL}$ are widely used as the first indication of PCa, mainly when the abnormal result is double-checked [38]. Similarly to BPH, PSA levels are combined 
with digital rectal examination and prostate imaging tests to screen for early PCa, which is generally asymptomatic [39]. Prostate biopsy, in turn, is the gold standard diagnostic technique for detecting PCa [40].

The Gleason scoring system is a pivotal component of PCa diagnosis and is often used to guide decision-making [41]. Such a scoring system quantifies the histological prostate pattern through five grades consisting of the sum of two numbers representing the Gleason grade of the predominant pattern added to the grade of the next most common pattern. A Gleason score less than 6 is classified as grade 1 and has the lowest clinical magnitude; grade 2 is composed of a score of 7 with the number 3 as a predominant pattern $(3+4=7)$; a sum of 7 with the number 4 as a predominant pattern $(4+3=7)$ is classified as grade 3 ; Gleason score $>7$ with grades 4 and 5 involves poorly differentiated tumors and represents the worst prognosis [42,43].

The presence or absence of symptoms and other associated comorbidities, as well as patient preferences, are key factors in determining the treatment of PCa [44]. Treatment options for localized PCa according to cancer severity/risk group involve active surveillance, radical prostatectomy, and radiation therapy with or without androgen deprivation therapy [45].

\section{Clinical Findings}

5.1. Evidence for Testosterone Replacement Therapy in Benign Prostatic Hyperplasia and Prostate Cancer

Notwithstanding all the concerns about TRT and its suggested side effects in BPH and $\mathrm{PCa}$, massive research brings important data that are in favor of patients suffering from prostate disorders. Evidence synthesis with and without a meta-analysis geared toward safety is collectively discussed in the following subsections.

\subsubsection{Synthesis without a Meta-Analysis}

A study that prospectively examined men with symptomatic late-onset hypogonadism revealed that TRT improved not only sexual function, but also bladder function by increasing its capacity and compliance while decreasing detrusor pressure at the maximum flow rate [46].

A study evaluating 30 patients who underwent supraphysiological doses $(200 \mathrm{mg} / \mathrm{wk}$, IM) of T for contraception purposes over an 18-month period (12 months of treatment plus 6 months after discontinuation) reported that, despite a sustained increase in serum levels of T, estradiol, and DHT during treatment, there was no detectable increase in prostate size on digital rectal examination or any significant change in PSA concentrations [47]. A small but significant increase $(14.3 \pm 2.0 \%)$ in the maximal prostate transverse area was noted in four men, whereas no alteration was observed in the other patients [47].

Of note, low $\mathrm{T}$ levels can be considered a prognostic marker for high-grade $\mathrm{PCa}$, as proposed by a study that investigated individuals with a biopsy Gleason score of 8 or greater [48]. Correspondingly, lower T levels are observed in patients with advanced-stage PCa [49]. Taking into account the relevance of this laboratory relationship, the effects of TRT in patients with aggressive PCa are discussed below.

In an epidemiological study assessing 1181 men who received TRT after PCa diagnosis, such a hormone treatment was not associated with increased overall or cancer-specific mortality [50]. In a retrospective cohort study of male veterans (40 to 89 years) addressing 313 patients with aggressive PCa on TRT, when compared to 190 untreated men, TRT was not associated with incident aggressive PCa (hazard ratio (HR), 0.89; 95\% CI, 0.70-1.13) or any PCa (HR, 0.90; 95\% CI, 0.81-1.01) when fully adjusted (age, race, hospitalization during the year prior to cohort entry, geography, BMI, medical comorbidities, repeated $\mathrm{T}$ and PSA screening) [51].

To date, however, debate persists as to whether TRT is problematic or beneficial for PCa progression. For instance, from the 57 studies selected in a systematic review examining the effects of TRT on the risk of PCa, only six studies explored this issue, of which two did 
not observe clinical PCa progression while the Gleason score increased in $8-15 \%$ of patients in the other studies [52].

\subsubsection{Meta-Analyses}

A meta-analysis of randomized controlled trials (RCTs) in men who underwent TRT reported that the combined rate of all prostate events was significantly higher in T-treated men than in the placebo group (odds ratio $(\mathrm{OR})=1.78 ; 95 \% \mathrm{CI}, 1.07-2.95$ ). Rates of PCa, PSA $>4 \mathrm{ng} / \mathrm{mL}$, and prostate biopsies were numerically higher in the $\mathrm{T}$ group than in the placebo group [53].

A meta-analysis of RCTs assessing the efficacy and safety of TRT in men with hypogonadism found an increase in prostate volume (median difference (MD), 1.58; 95\% CI, 0.6-2.56; $p=0.002$ ) after TRT, but PSA levels and International Prostate Symptom Scores (IPSS) did not change [54].

A meta-analysis of RCTs and non-RCTs (total of 51 studies) found no significant effect of TRT on the incidence of PCa or the need for prostate biopsy when compared with a placebo [55]. Furthermore, there was no significant difference between the groups in the risk of other prostatic and urological outcomes, such as PSA levels and changes in IPSS.

In a meta-analysis of 14 RCTs ( $n=2029$ subjects) examining TRT for late-onset hypogonadism, TRT did not worsen LUTS compared with a placebo [56]. There was no statistical significance for IPSS from the baseline to the TRT follow-up period compared to those who received a placebo irrespective of $\mathrm{T}$ formulations (topical, injectable, and oral administration) [56]. Moreover, a meta-analysis of 22 RCTs involving a total of 2351 patients found that TRT administered transdermally, orally, or by injection did not differ in the risk of PCa development; neither short-term ( $<12$ months) nor long-term TRT (12-36 months) affected the PCa incidence [57].

A meta-analysis addressing 15 RCTs showed that TRT was not associated with a higher risk of developing PCa, although PSA levels rose and plateaued relative to the placebo groups [58].

Regarding meta-analyses of observational studies, one conducted to determine the relationship between TRT and the risk of recurrence in T-deficient survivors of curatively treated high-risk PCa showed that the biochemical recurrence (BCR) rate was lower than expected, thereby implying that TRT can have null effects for BCR risk [59]. In another meta-analysis including prospective and retrospective studies that evaluated hypogonadal patients with PCa, TRT after definitive PCa therapy was considered oncologically safe because it did not increase the BCR rate [60].

Taken together, the design, population, and main results of these meta-analyses are summarized in Table 1.

Table 1. Meta-analyses evaluating the risk of BPH and PCa development in patients undergoing TRT.

\begin{tabular}{|c|c|c|c|c|c|}
\hline Study & $\begin{array}{l}\text { Design (Number } \\
\text { of Studies) }\end{array}$ & Population & $\begin{array}{c}\text { Route of } \\
\text { Administration }\end{array}$ & $\begin{array}{l}\text { Duration } \\
\text { (Months) }\end{array}$ & Outcomes \\
\hline $\begin{array}{l}\text { Parizi et al., } \\
2019 \text { [60] }\end{array}$ & $\begin{array}{l}\text { Prospective and } \\
\text { retrospective } \\
\quad(\mathrm{n}=21)\end{array}$ & $\begin{array}{l}\text { PCa men treated } \\
\text { with TRT after } \\
\text { definitive local } \\
\text { therapy }(\mathrm{n}=1084)\end{array}$ & TD; IM; PO & $1-102$ & $\begin{array}{c}\text { TRT after definitive PCa } \\
\text { therapy appears to be safe } \\
\text { and does not increase the } \\
\text { BCR rate }\end{array}$ \\
\hline $\begin{array}{l}\text { Teeling et al., } \\
2018 \text { [59] }\end{array}$ & $\begin{array}{l}\text { Prospective and } \\
\text { retrospective } \\
\quad(n=13)\end{array}$ & $\begin{array}{l}\text { High-risk PCa } \\
\text { survivors } \\
\text { undergoing TRT } \\
\quad(\mathrm{n}=109)\end{array}$ & $\begin{array}{l}\text { TD patch; TD gel } \\
\text { TU IM PO Pellet }\end{array}$ & $1-189$ & No increased risk of BCR \\
\hline
\end{tabular}


Table 1. Cont.

\begin{tabular}{|c|c|c|c|c|c|}
\hline Study & $\begin{array}{l}\text { Design (Number } \\
\text { of Studies) }\end{array}$ & Population & $\begin{array}{c}\text { Route of } \\
\text { Administration }\end{array}$ & $\begin{array}{l}\text { Duration } \\
\text { (Months) }\end{array}$ & Outcomes \\
\hline $\begin{array}{l}\text { Guo et al., } \\
2016 \text { [54] }\end{array}$ & RCTs $(n=16)$ & $\begin{array}{c}\text { Men with T } \\
\text { deficiency; } \\
\text { comparison of } \\
\text { TRT-treated and } \\
\text { placebo-treated } \\
\text { patients }(\mathrm{n}=1921)\end{array}$ & $\begin{array}{l}\text { TE IM; TU, PO; } \\
\text { TD gel; TU IM }\end{array}$ & $6-36$ & $\begin{array}{c}\text { IPSS did not change } \\
\text { significantly in the TRT } \\
\text { group. TRT also improved } \\
\text { life quality, } \\
\text { anthropometric status, } \\
\text { and metabolic parameters }\end{array}$ \\
\hline $\begin{array}{l}\text { Kohn et al., } \\
2016 \text { [56] }\end{array}$ & RCTs $(n=14)$ & $\begin{array}{l}\text { TRT for men with } \\
\text { LOH and LUTS } \\
\text { assessed }(n=2029)\end{array}$ & $\begin{array}{l}\text { TD patch; TD gel; } \\
\text { TE IM; TU IM; } \\
\text { TU, PO }\end{array}$ & $3-36$ & $\begin{array}{l}\text { No statistical significance } \\
\text { for IPSS from the baseline } \\
\text { to the end of the follow-up } \\
\text { period in the men treated } \\
\text { with TRT compared to the } \\
\text { placebo group }\end{array}$ \\
\hline $\begin{array}{l}\text { Kang and Li, } \\
2015 \text { [58] }\end{array}$ & RCTs $(n=15)$ & $\begin{array}{l}\text { Men undergoing } \\
\text { TRT }(\mathrm{n}=739)\end{array}$ & $\begin{array}{l}\text { TD patch; TD gel; } \\
\text { TE IM; TU IM } \\
\text { TU PO }\end{array}$ & $3-12$ & $\begin{array}{l}\text { TRT seemingly did not } \\
\text { increase the risk of PCa }\end{array}$ \\
\hline $\begin{array}{l}\text { Cui et al., } \\
2014 \text { [57] }\end{array}$ & $\operatorname{RCTs}(\mathrm{n}=22)$ & $\begin{array}{l}\text { Men undergoing } \\
\text { TRT }(\mathrm{n}=2351)\end{array}$ & $\begin{array}{l}\text { TD patch; TD gel; } \\
\text { TE IM; TU IM } \\
\text { TU, PO }\end{array}$ & $3-36$ & $\begin{array}{l}\text { TRT had short-term safety } \\
\text { and did not promote PCa } \\
\text { development or } \\
\text { progression }\end{array}$ \\
\hline
\end{tabular}

Fernández-

Balsells et al. 2010 [55]

RCTs and
non-RCTs $(n=51)$

Men with low or
low-normal T

levels and treated with any $\mathrm{T}$

formulation for at

least three months $(\mathrm{n}=2798)$
TD patch; TD gel;

TE IM; TU IM; TU, PO
There was no significant difference between TRT and the placebo in PSA levels and IPSS
Men $\geq 45$ years old with low or

Calof et al., 2005 [53]
RCTs ( $\mathrm{n}=19)$

\section{low-normal T}

levels (651 subjects treated with $\mathrm{T}$ and 433 subjects treated with a placebo)

TU IM; TE IM;
TC IM; ME IM;
scrotal patch; TU,
PO; TD patch;
$\quad$ TD gel

3-36 
95\% CI, 0.43-0.95) and 28\% (OR = 0.72; 95\% CI, 0.53-0.98) lower likelihood of having $\mathrm{BPH}$, respectively [67]. In addition, a higher T:17 $\beta$-diol glucuronide ratio was associated with a $36 \%$ lower likelihood of having $\mathrm{BPH}(\mathrm{OR}=0.64 ; 95 \% \mathrm{CI}, 0.46-0.89)$. In this sense, controls had higher $\mathrm{T}$ ( $521 \pm 93$ vs. $492 \pm 186 \mathrm{ng} / \mathrm{dl}, p=0.005)$, bioavailable $\mathrm{T}$ (305 \pm 99 vs. $289 \pm 94 \mathrm{ng} / \mathrm{dl}, p=0.002)$, estradiol ( $32 \pm 9$ vs. $30 \pm 9 \mathrm{pg} / \mathrm{mL}, p=0.035)$, and $17 \beta$-diol glucuronide (104 \pm 69 vs. $96 \pm 70, p=0.036)$ levels compared to cases. Although the research design does not infer causation, the null effect of higher endogenous $\mathrm{T}$ levels on $\mathrm{BPH}$ is a crucial finding to furnish common laboratory ranges without TRT interference. Equally important, the results collectively suggest decreased activity of 5-alpha-reductase in the pathophysiology of $\mathrm{BPH}$, as $17 \beta$-diol glucuronide is an indirect measure of DHT formation.

New data suggest a role of estradiol in prostate carcinogenesis mediated by estrogen receptor subtypes which are highly expressed in prostasphere undifferentiated cells, indicating that prostate progenitor cells are a target for estrogen and its proliferative effects [68] Other estrogen-related mechanisms have been proposed, e.g., direct mutagenic effects on DNA and epigenotoxicity, but the findings are incipient, and hence further studies are warranted [69].

Despite attractive mechanistic actions, no association was found between serum estrogen levels and PCa risk in a nested case-control study encompassing 1798 biopsyproven PCa cases and 1798 matched controls [70].

\section{Strengths and Limitations}

This review can guide clinicians by summarizing the overall effects of TRT on BPH and $\mathrm{PCa}$, shedding light on the safety of a disputable area in medicine related to widespread clinical beliefs and judgments without proper scientific scrutiny. Even providing a framework for clinicians, this article does not have the same significance as meta-analyses and evidence grade as guidelines, but at least unifies the compelling meta-analyses published thus far.

Intrinsic limitations are conceivable among the studies, as well as heterogeneity regarding the posology of TRT. For instance, while 75 to $100 \mathrm{mg}$ / week or 150-200 mg every two weeks of intramuscular administration of $\mathrm{T}$ is the common therapeutic regimen, there are some nuances for pharmacokinetics and pharmacodynamics due to different esters (e.g., undecanoate, enanthate, cypionate, and propionate) [71-73]. Not surprisingly, controversies are more evident when embarking on other routes of administration (e.g., subcutaneous, topical, and oral) due to the discrepancy to reach stable T levels [74]. Despite the appealing wide spread of topical $\mathrm{T}$ gel, slight and great differences of $\mathrm{T}$ concentrations across gel formulations and their bioavailability depending on the topical application sites can affect the medical approach when particular pharmacological facets are neglected $[75,76]$.

Ultimately, we reiterate that complementary literature is mandatory for clinicians who deal with TRT prescription so that dosing regimens can be personalized. This review does not address recommendations, and thus guidelines from high-impact medical journals cannot be ruled out.

\section{Conclusions}

Low $\mathrm{T}$ levels and accompanying metabolic disorders appear to have a greater negative impact on BPH and PCa than the caveats for TRT, so much so that TRT has a reasonable safety margin and, at proper dosing regimens, may assist in metabolic regulation. The risks of TRT for prostate disorders such as BPH and PCa seem to be overestimated. Even after treatment for $\mathrm{PCa}$, the benefits of TRT could outweigh the risk of recurrence; however, future long-term RCTs are needed to draw solid conclusions.

Author Contributions: Conceptualization, H.O.S. and A.R.; methodology, H.O.S. and A.R.; investigation, H.O.S., A.R. and G.S.; data curation, H.O.S.; writing-original draft preparation, A.R., G.S. and H.O.S.; writing-review and editing, H.O.S.; supervision, H.O.S.; project administration, H.O.S. All authors have read and agreed to the published version of the manuscript. 
Funding: The authors were supported by Coordenação de Aperfeiçoamento de Pessoal de Nível Superior-Brazil (CAPES)

Institutional Review Board Statement: Not applicable.

Informed Consent Statement: Not applicable.

Data Availability Statement: Not applicable.

Conflicts of Interest: The authors declare no conflict of interest.

\section{References}

1. Feldman, H.A.; Longcope, C.; Derby, C.A.; Johannes, C.B.; Araujo, A.B.; Coviello, A.D.; Bremner, J.; McKinlay, J.B. Age trends in the level of serum testosterone and other hormones in middle-aged men: Longitudinal results from the Massachusetts male aging study. J. Clin. Endocrinol. Metab. 2002, 87, 589-598. [CrossRef]

2. Santos, H.O.; Howell, S.; Teixeira, F.J. Beyond tribulus (Tribulus terrestris L.): The effects of phytotherapics on testosterone, sperm and prostate parameters. J. Ethnopharmacol. 2019, 235, 392-405. [CrossRef]

3. Santos, H.O.; Teixeira, F.J. Use of medicinal doses of zinc as a safe and efficient coadjutant in the treatment of male hypogonadism. Aging Male Off. J. Int. Soc. Study Aging Male 2020, 23, 669-678. [CrossRef] [PubMed]

4. Santos, H.O.; Howell, S.; Nichols, K.; Teixeira, F.J. Reviewing the Evidence on Vitamin D Supplementation in the Management of Testosterone Status and Its Effects on Male Reproductive System (Testis and Prostate): Mechanistically Dazzling but Clinically Disappointing. Clin. Ther. 2020, 42, e101-e114. [CrossRef] [PubMed]

5. Santos, H.O. Ketogenic diet and testosterone increase: Is the increased cholesterol intake responsible? To what extent and under what circumstances can there be benefits? Hormones 2017, 16, 150-160. [CrossRef]

6. McBride, J.A.; Carson, C.C., 3rd; Coward, R.M. Testosterone deficiency in the aging male. Ther. Adv. Urol. 2016, 8, 47-60. [CrossRef]

7. Harman, S.M.; Metter, E.J.; Tobin, J.D.; Pearson, J.; Blackman, M.R. Longitudinal effects of aging on serum total and free testosterone levels in healthy men. Baltimore Longitudinal Study of Aging. J. Clin. Endocrinol. Metab. 2001, 86, 724-731. [CrossRef] [PubMed]

8. Dandona, P.; Rosenberg, M.T. A practical guide to male hypogonadism in the primary care setting. Int. J. Clin. Pract. 2010, 64, 682-696. [CrossRef]

9. Peterson, M.D.; Belakovskiy, A.; McGrath, R.; Yarrow, J.F. Testosterone Deficiency, Weakness, and Multimorbidity in Men. Sci. Rep. 2018, 8, 5897. [CrossRef] [PubMed]

10. Mulligan, T.; Frick, M.F.; Zuraw, Q.C.; Stemhagen, A.; McWhirter, C. Prevalence of hypogonadism in males aged at least 45 years: The HIM study. Int. J. Clin. Pract. 2006, 60, 762-769. [CrossRef] [PubMed]

11. Araujo, A.B.; Dixon, J.M.; Suarez, E.A.; Murad, M.H.; Guey, L.T.; Wittert, G.A. Clinical review: Endogenous testosterone and mortality in men: A systematic review and meta-analysis. J. Clin. Endocrinol. Metab. 2011, 96, 3007-3019. [CrossRef]

12. Corona, G.; Rastrelli, G.; Di Pasquale, G.; Sforza, A.; Mannucci, E.; Maggi, M. Endogenous Testosterone Levels and Cardiovascular Risk: Meta-Analysis of Observational Studies. J. Sex. Med. 2018, 15, 1260-1271. [CrossRef] [PubMed]

13. Malkin, C.J.; Pugh, P.J.; Morris, P.D.; Asif, S.; Jones, T.H.; Channer, K.S. Low serum testosterone and increased mortality in men with coronary heart disease. Heart 2010, 96, 1821-1825. [CrossRef] [PubMed]

14. Shores, M.M. Testosterone treatment and cardiovascular events in prescription database studies. Asian J. Androl. 2018, 20, 138-144. [CrossRef]

15. Wittert, G.; Bracken, K.; Robledo, K.P.; Grossmann, M.; Yeap, B.B.; Handelsman, D.J.; Stuckey, B.; Conway, A.; Inder, W.; McLachlan, R.; et al. Testosterone treatment to prevent or revert type 2 diabetes in men enrolled in a lifestyle programme (T4DM): A randomised, double-blind, placebo-controlled, 2-year, phase 3b trial. Lancet Diabetes Endocrinol. 2021, 9, 32-45. [CrossRef]

16. Khera, M.; Bhattacharya, R.K.; Blick, G.; Kushner, H.; Nguyen, D.; Miner, M.M. Improved sexual function with testosterone replacement therapy in hypogonadal men: Real-world data from the Testim Registry in the United States (TRiUS). J. Sex. Med. 2011, 8, 3204-3213. [CrossRef] [PubMed]

17. Bhasin, S.; Woodhouse, L.; Casaburi, R.; Singh, A.B.; Bhasin, D.; Berman, N.; Chen, X.; Yarasheski, K.E.; Magliano, L.; Dzekov, C.; et al. Testosterone dose-response relationships in healthy young men. Am. J. Physiol. Endocrinol. Metab. 2001, 281, E1172-E1181. [CrossRef]

18. Cunningham, G.R.; Ellenberg, S.S.; Bhasin, S.; Matsumoto, A.M.; Parsons, J.K.; Preston, P.; Cauley, J.A.; Gill, T.M.; Swerdloff, R.S.; Wang, C.; et al. Prostate-Specific Antigen Levels During Testosterone Treatment of Hypogonadal Older Men: Data from a Controlled Trial. J. Clin. Endocrinol. Metab. 2019, 104, 6238-6246. [CrossRef]

19. Bray, F.; Ferlay, J.; Soerjomataram, I.; Siegel, R.L.; Torre, L.A.; Jemal, A. Global cancer statistics 2018: GLOBOCAN estimates of incidence and mortality worldwide for 36 cancers in 185 countries. CA A Cancer J. Clin. 2018, 68, 394-424. [CrossRef]

20. Roehrborn, C.G.; Black, L.K. The economic burden of prostate cancer. BJU Int. 2011, 108, 806-813. [CrossRef]

21. Hao, S.; Ostensson, E.; Eklund, M.; Gronberg, H.; Nordstrom, T.; Heintz, E.; Clements, M. The economic burden of prostate cancer-A Swedish prevalence-based register study. BMC Health Serv. Res. 2020, 20, 448. [CrossRef]

22. Randall, V.A. Role of 5 alpha-reductase in health and disease. Baillieres Clin. Endocrinol. Metab. 1994, 8, 405-431. [CrossRef] 
23. Cilotti, A.; Danza, G.; Serio, M. Clinical application of 5alpha-reductase inhibitors. J. Endocrinol. Investig. 2001, $24,199-203$. [CrossRef] [PubMed]

24. Izumi, K.; Li, L.; Chang, C. Androgen receptor and immune inflammation in benign prostatic hyperplasia and prostate cancer. Clin. Investig. 2014, 4, 935-950. [CrossRef]

25. Lee, J.J.; Thomas, I.C.; Nolley, R.; Ferrari, M.; Brooks, J.D.; Leppert, J.T. Biologic differences between peripheral and transition zone prostate cancer. Prostate 2015, 75, 183-190. [CrossRef] [PubMed]

26. Lim, K.B. Epidemiology of clinical benign prostatic hyperplasia. Asian J. Urol. 2017, 4, 148-151. [CrossRef]

27. Jones, D.; Friend, C.; Dreher, A.; Allgar, V.; Macleod, U. The diagnostic test accuracy of rectal examination for prostate cancer diagnosis in symptomatic patients: A systematic review. BMC Fam. Pract. 2018, 19, 79. [CrossRef] [PubMed]

28. Roehrborn, C.G.; Girman, C.J.; Rhodes, T.; Hanson, K.A.; Collins, G.N.; Sech, S.M.; Jacobsen, S.J.; Garraway, W.M.; Lieber, M.M. Correlation between prostate size estimated by digital rectal examination and measured by transrectal ultrasound. Urology 1997, 49, 548-557. [CrossRef]

29. Barry, M.J.; Fowler, F.J., Jr.; O’Leary M, P.; Bruskewitz, R.C.; Holtgrewe, H.L.; Mebust, W.K.; Cockett, A.T.; The Measurement Committee of the American Urological Association. The American Urological Association Symptom Index for Benign Prostatic Hyperplasia. J. Urol. 2017, 197, S189-S197. [CrossRef] [PubMed]

30. Batista-Miranda, J.E.; Molinuevo, B.; Pardo, Y. Impact of lower urinary tract symptoms on quality of life using Functional Assessment Cancer Therapy scale. Urology 2007, 69, 285-288. [CrossRef]

31. Yalla, S.V.; Sullivan, M.P.; Lecamwasam, H.S.; DuBeau, C.E.; Vickers, M.A.; Cravalho, E.G. Correlation of American Urological Association symptom index with obstructive and nonobstructive prostatism. J. Urol. 1995, 153, 674-679. [CrossRef]

32. Monda, J.M.; Oesterling, J.E. Medical treatment of benign prostatic hyperplasia: 5 alpha-reductase inhibitors and alpha-adrenergic antagonists. Mayo Clin. Proc. 1993, 68, 670-679. [CrossRef]

33. Lerner, L.B.; McVary, K.T.; Barry, M.J.; Bixler, B.R.; Dahm, P.; Das, A.K.; Gandhi, M.C.; Kaplan, S.A.; Kohler, T.S.; Martin, L.; et al. Management of Lower Urinary Tract Symptoms Attributed to Benign Prostatic Hyperplasia: AUA GUIDELINE PART I-Initial Work-up and Medical Management. J. Urol. 2021, 206, 806-817. [CrossRef] [PubMed]

34. Andriole, G.; Bruchovsky, N.; Chung, L.W.; Matsumoto, A.M.; Rittmaster, R.; Roehrborn, C.; Russell, D.; Tindall, D. Dihydrotestosterone and the prostate: The scientific rationale for 5alpha-reductase inhibitors in the treatment of benign prostatic hyperplasia. $J$. Urol. 2004, 172, 1399-1403. [CrossRef]

35. Swyer, G.I. Post-natal growth changes in the human prostate. J. Anat. 1944, 78, 130-145.

36. Huggins, C. The Etiology of Benign Prostatic Hypertrophy. Bull. N. Y. Acad. Med. 1947, 23, 696-704.

37. Gann, P.H.; Hennekens, C.H.; Longcope, C.; Verhoek-Oftedahl, W.; Grodstein, F.; Stampfer, M.J. A prospective study of plasma hormone levels, nonhormonal factors, and development of benign prostatic hyperplasia. Prostate 1995, 26, 40-49. [CrossRef]

38. Hernández, J.; Thompson, I.M. Prostate-specific antigen: A review of the validation of the most commonly used cancer biomarker. Cancer 2004, 101, 894-904. [CrossRef]

39. Okotie, O.T.; Roehl, K.A.; Han, M.; Loeb, S.; Gashti, S.N.; Catalona, W.J. Characteristics of prostate cancer detected by digital rectal examination only. Urology 2007, 70, 1117-1120. [CrossRef]

40. Streicher, J.; Meyerson, B.L.; Karivedu, V.; Sidana, A. A review of optimal prostate biopsy: Indications and techniques. Ther. Adv. Urol. 2019, 11, 1756287219870074. [CrossRef]

41. Tagai, E.K.; Miller, S.M.; Kutikov, A.; Diefenbach, M.A.; Gor, R.A.; Al-Saleem, T.; Chen, D.Y.T.; Fleszar, S.; Roy, G. Prostate Cancer Patients' Understanding of the Gleason Scoring System: Implications for Shared Decision-Making. J. Cancer Educ. Off. J. Am. Assoc. Cancer Educ. 2019, 34, 441-445. [CrossRef] [PubMed]

42. Gordetsky, J.; Epstein, J. Grading of prostatic adenocarcinoma: Current state and prognostic implications. Diagn. Pathol. 2016, 11, 25. [CrossRef] [PubMed]

43. Pierorazio, P.M.; Walsh, P.C.; Partin, A.W.; Epstein, J.I. Prognostic Gleason grade grouping: Data based on the modified Gleason scoring system. BJU Int. 2013, 111, 753-760. [CrossRef] [PubMed]

44. Sanda, M.G.; Cadeddu, J.A.; Kirkby, E.; Chen, R.C.; Crispino, T.; Fontanarosa, J.; Freedland, S.J.; Greene, K.; Klotz, L.H.; Makarov, D.V.; et al. Clinically Localized Prostate Cancer: AUA/ASTRO/SUO Guideline. Part I: Risk Stratification, Shared Decision Making, and Care Options. J. Urol. 2018, 199, 683-690. [CrossRef]

45. Bekelman, J.E.; Rumble, R.B.; Chen, R.C.; Pisansky, T.M.; Finelli, A.; Feifer, A.; Nguyen, P.L.; Loblaw, D.A.; Tagawa, S.T.; Gillessen, S.; et al. Clinically Localized Prostate Cancer: ASCO Clinical Practice Guideline Endorsement of an American Urological Association/American Society for Radiation Oncology/Society of Urologic Oncology Guideline. J. Clin. Oncol. 2018, 36, 3251-3258. [CrossRef]

46. Karazindiyanoğlu, S.; Cayan, S. The effect of testosterone therapy on lower urinary tract symptoms/bladder and sexual functions in men with symptomatic late-onset hypogonadism. Aging Male 2008, 11, 146-149. [CrossRef]

47. Wallace, E.M.; Pye, S.D.; Wild, S.R.; Wu, F.C. Prostate-specific antigen and prostate gland size in men receiving exogenous testosterone for male contraception. Int. J. Androl. 1993, 16, 35-40. [CrossRef]

48. Hoffman, M.A.; DeWolf, W.C.; Morgentaler, A. Is low serum free testosterone a marker for high grade prostate cancer? J. Urol. 2000, 163, 824-827. [CrossRef]

49. Mearini, L.; Costantini, E.; Zucchi, A.; Mearini, E.; Bini, V.; Cottini, E.; Porena, M. Testosterone levels in benign prostatic hypertrophy and prostate cancer. Urol. Int. 2008, 80, 134-140. [CrossRef] 
50. Kaplan, A.L.; Trinh, Q.D.; Sun, M.; Carter, S.C.; Nguyen, P.L.; Shih, Y.T.; Marks, L.S.; Hu, J.C. Testosterone replacement therapy following the diagnosis of prostate cancer: Outcomes and utilization trends. J. Sex. Med. 2014, 11, 1063-1070. [CrossRef]

51. Walsh, T.J.; Shores, M.M.; Krakauer, C.A.; Forsberg, C.W.; Fox, A.E.; Moore, K.P.; Korpak, A.; Heckbert, S.R.; Zeliadt, S.B.; Kinsey, C.E.; et al. Testosterone treatment and the risk of aggressive prostate cancer in men with low testosterone levels. PLoS ONE 2018, 13, e0199194. [CrossRef] [PubMed]

52. Lenfant, L.; Leon, P.; Cancel-Tassin, G.; Audouin, M.; Staerman, F.; Rouprêt, M.; Cussenot, O. Testosterone replacement therapy (TRT) and prostate cancer: An updated systematic review with a focus on previous or active localized prostate cancer. Urol. Oncol. 2020, 38, 661-670. [CrossRef] [PubMed]

53. Calof, O.M.; Singh, A.B.; Lee, M.L.; Kenny, A.M.; Urban, R.J.; Tenover, J.L.; Bhasin, S. Adverse events associated with testosterone replacement in middle-aged and older men: A meta-analysis of randomized, placebo-controlled trials. J. Gerontol. A Biol. Sci. Med. Sci. 2005, 60, 1451-1457. [CrossRef] [PubMed]

54. Guo, C.; Gu, W.; Liu, M.; Peng, B.O.; Yao, X.; Yang, B.; Zheng, J. Efficacy and safety of testosterone replacement therapy in men with hypogonadism: A meta-analysis study of placebo-controlled trials. Exp. Ther. Med. 2016, 11, 853-863. [CrossRef]

55. Fernández-Balsells, M.M.; Murad, M.H.; Lane, M.; Lampropulos, J.F.; Albuquerque, F.; Mullan, R.J.; Agrwal, N.; Elamin, M.B.; Gallegos-Orozco, J.F.; Wang, A.T.; et al. Clinical review 1: Adverse effects of testosterone therapy in adult men: A systematic review and meta-analysis. J. Clin. Endocrinol. Metab. 2010, 95, 2560-2575. [CrossRef]

56. Kohn, T.P.; Mata, D.A.; Ramasamy, R.; Lipshultz, L.I. Effects of Testosterone Replacement Therapy on Lower Urinary Tract Symptoms: A Systematic Review and Meta-analysis. Eur. Urol. 2016, 69, 1083-1090. [CrossRef]

57. Cui, Y.; Zong, H.; Yan, H.; Zhang, Y. The effect of testosterone replacement therapy on prostate cancer: A systematic review and meta-analysis. Prostate Cancer Prostatic Dis. 2014, 17, 132-143. [CrossRef]

58. Kang, D.Y.; Li, H.J. The effect of testosterone replacement therapy on prostate-specific antigen (PSA) levels in men being treated for hypogonadism: A systematic review and meta-analysis. Medicine 2015, 94, e410. [CrossRef]

59. Teeling, F.; Raison, N.; Shabbir, M.; Yap, T.; Dasgupta, P.; Ahmed, K. Testosterone Therapy for High-risk Prostate Cancer Survivors: A Systematic Review and Meta-analysis. Urology 2019, 126, 16-23. [CrossRef]

60. Kardoust Parizi, M.; Abufaraj, M.; Fajkovic, H.; Kimura, S.; Iwata, T.; D'Andrea, D.; Karakiewicz, P.I.; Shariat, S.F. Oncological safety of testosterone replacement therapy in prostate cancer survivors after definitive local therapy: A systematic literature review and meta-analysis. Urol. Oncol. 2019, 37, 637-646. [CrossRef]

61. Shi, H.; Santos, H.O.; De Souza, I.G.O.; Hoilat, G.J.; Martins, C.E.C.; Varkaneh, H.K.; Alkhwildi, J.A.; Hejji, A.T.; Almuqayyid, F.; Abu-Zaid, A. The Effect of Raloxifene Treatment on Lipid Profile in Elderly Individuals: A Systematic Review and Meta-analysis of Randomized Clinical Trials. Clin. Ther. 2021, 43, 297-317. [CrossRef] [PubMed]

62. Cai, T.; Al-Jubairi, N.N.; Santos, H.O.; De Souza, I.G.O.; Chen, Y. Does letrozole treatment have favorable effects on the lipid profile? A systematic review and meta-analysis of randomized clinical trials. Steroids 2021, 172, 108875. [CrossRef] [PubMed]

63. Sun, Y.; Xiong, Y.; Meng, Y.L.; Santos, H.O.; Athayde, F.L.; De Souza, I.G.O.; Yang, L. Effects of raloxifene administration on serum levels of insulin-like growth factor-1 and insulin-like growth factor-binding protein 3 levels: A systematic review and meta-analysis of randomized controlled trials. Growth Horm. IGF Res. 2021, 60-61, 101421. [CrossRef]

64. Tan, R.S.; Cook, K.R.; Reilly, W.G. High estrogen in men after injectable testosterone therapy: The low T experience. Am. J. Mens. Health 2015, 9, 229-234. [CrossRef] [PubMed]

65. Schulster, M.; Bernie, A.M.; Ramasamy, R. The role of estradiol in male reproductive function. Asian J. Androl. 2016, 18, 435-440. [CrossRef] [PubMed]

66. Roberts, R.O.; Jacobson, D.J.; Rhodes, T.; Klee, G.G.; Leiber, M.M.; Jacobsen, S.J. Serum sex hormones and measures of benign prostatic hyperplasia. Prostate 2004, 61, 124-131. [CrossRef]

67. Kristal, A.R.; Schenk, J.M.; Song, Y.; Arnold, K.B.; Neuhouser, M.L.; Goodman, P.J.; Lin, D.W.; Stanczyk, F.Z.; Thompson, I.M. Serum steroid and sex hormone-binding globulin concentrations and the risk of incident benign prostatic hyperplasia: Results from the prostate cancer prevention trial. Am. J. Epidemiol. 2008, 168, 1416-1424. [CrossRef] [PubMed]

68. Hu, W.Y.; Shi, G.B.; Lam, H.M.; Hu, D.P.; Ho, S.M.; Madueke, I.C.; Kajdacsy-Balla, A.; Prins, G.S. Estrogen-initiated transformation of prostate epithelium derived from normal human prostate stem-progenitor cells. Endocrinology 2011, 152, 2150-2163. [CrossRef]

69. Nelles, J.L.; Hu, W.Y.; Prins, G.S. Estrogen action and prostate cancer. Expert Rev. Endocrinol. Metab. 2011, 6, 437-451. [CrossRef]

70. Yao, S.; Till, C.; Kristal, A.R.; Goodman, P.J.; Hsing, A.W.; Tangen, C.M.; Platz, E.A.; Stanczyk, F.Z.; Reichardt, J.K.; Tang, L.; et al . Serum estrogen levels and prostate cancer risk in the prostate cancer prevention trial: A nested case-control study. Cancer Causes Control 2011, 22, 1121-1131. [CrossRef]

71. Shoskes, J.J.; Wilson, M.K.; Spinner, M.L. Pharmacology of testosterone replacement therapy preparations. Transl. Androl. Urol. 2016, 5, 834-843. [CrossRef]

72. Bi, Y.; Perry, P.J.; Ellerby, M.; Murry, D.J. Population Pharmacokinetic/Pharmacodynamic Modeling of Depot Testosterone Cypionate in Healthy Male Subjects. CPT Pharmacomet. Syst. Pharmacol. 2018, 7, 259-268. [CrossRef]

73. Partsch, C.J.; Weinbauer, G.F.; Fang, R.; Nieschlag, E. Injectable testosterone undecanoate has more favourable pharmacokinetics and pharmacodynamics than testosterone enanthate. Eur. J. Endocrinol. 1995, 132, 514-519. [CrossRef] [PubMed]

74. Scott, J.D.; Wolfe, P.R.; Anderson, P.; Cohan, G.R.; Scarsella, A. Prospective study of topical testosterone gel (AndroGel) versus intramuscular testosterone in testosterone-deficient HIV-infected men. HIV Clin. Trials 2007, 8, 412-420. [CrossRef] [PubMed] 
75. Guay, A.T.; Smith, T.M.; Offutt, L.A. Absorption of testosterone gel 1\% (Testim) from three different application sites. J. Sex. Med. 2009, 6, 2601-2610. [CrossRef] [PubMed]

76. Jockenhovel, F. Testosterone therapy-what, when and to whom? Aging Male Off. J. Int. Soc. Study Aging Male $2004,7,319-324$. [CrossRef] 